\title{
High Gain DC-DC Converter with Enhanced Adaptive MPPT for PV Applications
}

\author{
SUVETHA POYYAMANI SUNDDARARAJ*, AND SEYEZHAI RAMALINGAM*
}

RECEIVED ON 12.12.2018 ACCEPTED ON 03.05.2019

\begin{abstract}
The increasing demand for electricity has pushed more effort to focus on renewable energy sources to satisfy the consumer. The renewable energy sources are playing a major role in the generation of electricity. Out of all the renewable energy sources, solar has emerged as one of the best sources of energy since it is clean, inexhaustible and eco-friendly. However, the voltage generated by the solar cell is not sufficient for any consumer load and it is also variable. Therefore, it is necessary to implement DCDC converters for regulating and improving the output voltage of the solar panel. In order to extract the maximum output from the PV (Photovoltaic) panel, a comparative analysis of various MPPT (Maximum Power Point Tracking) algorithms is proposed in this paper. The proposed enhanced adaptive P\&O (Perturb and Observe) algorithm is modeled and implemented with a high gain DC-DC converter. The converter investigated in this paper consists of a single power electronic switch (MOSFET) for its operation, which leads to reduction of switching and conduction losses. The proposed converter has less ripple content and a high conversion ratio. A simulation study of the proposed power electronic converter powered by PV source is carried out in MATLAB/SIMULINK and the results are validated using an experimental setup.
\end{abstract}

Key Words: Enhanced Adaptive Perturb and Observe Algorithm, High Gain DC-DC Converter, Ripple, Photovoltaic.

\section{INTRODUCTION}

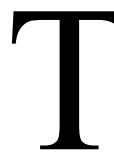

The PV energy generation has become the most predominant form of energy. This is due to the fact, that the energy generated by solar panel can be directly converted into direct current. Furthermore, the solar systems produce clean power, with no pollutant emissions, helping in such a way to strive against the global warming [1]. The output generated from the PV panel mainly depends upon the junction temperature and the solar insolation level.

The major problem in solar systems is that the operating characteristics of the load and the PV array are

Authors E-Mail: (suvetharaj16@gmail.com, seyezhair@ssn.edu.in)

* Department of Electrical \& Electronics Engineering, Sri Sivasubramaniya Nadar College of Engineering, Chennai, India 
mismatched. To obtain the optimum condition when it is directly connected to the load, a curve between the panel voltage and current is drawn and a point of intersection is determined. MPPT is then employed in the solar system to obtain the maximum power from the PV array and delivers it to the load. Maximum power is transferred to the load by varying the impedance on the load side and also matching it with the peak power at the instant of changing the duty cycle [2]. In this respect, several MPPT techniques are proposed. $\mathrm{P} \& \mathrm{O}$ is the simplest MPPT technique when compared to the conventional types and also exhibits very fast convergence to achieve the MPP (Maximum Power Point). But, the negative side of this method is that, when a perturbation occurs, the algorithm will force the operating point to continuously move in the region of the MPP [3]. Based on the level of perturbation, the power loss gets increased. The next drawback is that the $\mathrm{P} \& \mathrm{O}$ algorithm loses its tracking direction with respect to the irradiance level [4]. When the tracking direction gets deviated, the algorithm becomes mystified and it gets diverged from the MPP [5]. Another major drawback is the tracking of global peak under partial shading condition is poor. To overcome all these problems, an enhanced adaptive technique has been proposed in this paper.

Though maximum power is obtained from the PV panel, the regulation of output voltage is essential since it is variable in nature. Therefore, a power electronic converter has to be interfaced with the solar system. Apart from regulation, the voltage obtained from the PV should match the load side specifications. These issues have triggered a severe demand for the use of high efficient DC-DC converters [6].

To achieve high voltage gain, conventional boost converters with high duty ratio can be used. But, this leads to conduction losses and also results in reverse recovery problems. To overcome these problems, various researchers in the field of power electronic converters have come up with new modified topologies of high gain boost converters. The high gain converters that employ switched capacitors produce high transient current, thus reducing the life of the switched capacitor [7]. This drawback can be eliminated by the integration of voltage doubler circuit along with the switched inductor topology in order to achieve high voltage with reduction of stress across the switches on the power electronic devices [8]. But this scheme requires high number of switching devices, which makes the circuit configuration to be complex and the cost is also high. Therefore, quadratic boost converter is incorporated with the minimum number of switches. This requires transformer with large turns ratio which results in high leakage inductance, more voltage and current spikes on the power switches [9]. To overcome these problems, a single switch high gain boost converter by integrating a transformer-less quadratic boost converter with a conservative model of boost converter is proposed in this paper.

\section{PV MODELING AND CHARACTERISTICS}

A solar cell is basically a p-n junction which converts the light source into electricity through photovoltaic effect. When exposed to the sunlight, an electron-hole pair is created which is proportional to the incident radiation. A higher range of voltage and current can be attained by incorporating multiple cells [10]. The representation of PV cell is shown in Fig. 1.

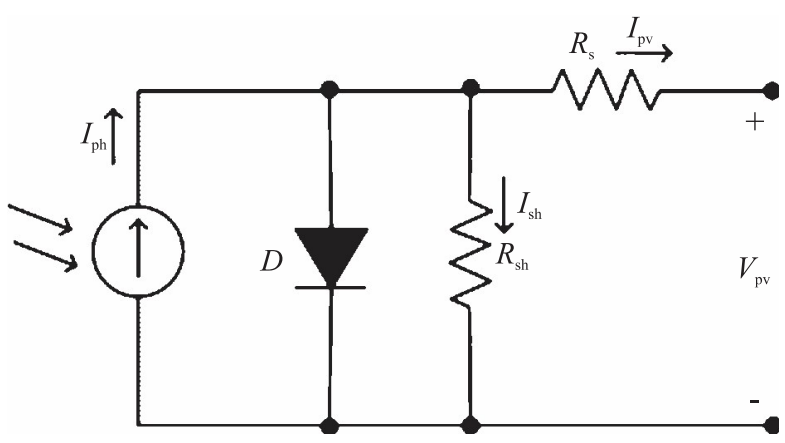

FIG. 1. EQUIVALENT CIRCUIT OF PV CELL [13] 
The series resistance and the shunt resistance correspond to the internal losses and the leakage current respectively. The output current is a function of solar radiation, temperature and various other parameters.

The PV modeling is done using the following Equations $(1-6)$

Photo current, $\mathrm{I}_{\mathrm{ph}}=\mathrm{I}_{\mathrm{sc}}+\left(\mathrm{ki}\left(\mathrm{T}_{\mathrm{op}}-\mathrm{T}_{\mathrm{ref}}\right) *\left(\mathrm{I}_{\mathrm{rr}}\right)\right.$

Reverse Saturation current, $\quad \mathrm{I}_{\mathrm{rs}}=\frac{\mathrm{Isc}}{\exp \left(\frac{\mathrm{qVOC}}{\text { NSKATop }}\right)^{-1}}$

Saturation Current, $I_{\mathrm{s}}=I_{\mathrm{rs}}\left[\frac{\mathrm{Top}}{\operatorname{Tref}}\right]^{3} * \exp \left[\left\{\frac{\mathrm{q}^{*} \mathrm{Eg} 0}{\mathrm{Ak}}\right\}\left\{\frac{1}{\operatorname{Tref}}-\frac{1}{\text { Top }}\right\}\right]$

Diode Current, $I_{d}=I_{s} * N_{p}\left[\exp \left\{\frac{q(V p v+\text { IpvRs })}{\text { NsAkTop }}\right\}-1\right]$

Shunt Current, $I_{\mathrm{sh}}=\frac{(\mathrm{Vpv}+\mathrm{IpvRs})}{\mathrm{Rsh}}$

Module Output Current, $\mathrm{I}_{\mathrm{pv}}=\left(\mathrm{I}_{\mathrm{ph}} * \mathrm{~N}_{\mathrm{p}}\right)-\mathrm{I}_{\mathrm{d}}-\mathrm{I}_{\mathrm{sh}}$

- $\mathrm{I}_{\mathrm{sc}}=$ short-circuit current in $\mathrm{A}$ and $\mathrm{K}_{\mathrm{i}}=$ temperature coefficient $(0.0017 \mathrm{~A} / \mathrm{K})$

- $\mathrm{T}_{\mathrm{op}}$ and $\mathrm{T}_{\text {ref }}=$ operating and reference temperatures in $\mathrm{K}$

- $\mathrm{I}_{\mathrm{rr}}=$ irradiation on the device surface $\left(\mathrm{W} / \mathrm{m}^{2}\right)$, and the nominal irradiation is $1000 \mathrm{~W} / \mathrm{m}^{2} .\left(\mathrm{I}_{\mathrm{rr}}=\mathrm{I}_{\mathrm{ro}} / 1000\right)$

- $\mathrm{q}=$ Charge of electron $(1.6 \times 10-19 \mathrm{C})$

- $\quad \mathrm{V}_{\mathrm{oc}}=$ Open-circuit voltage $(37.8 \mathrm{~V})$

- $\quad \mathrm{N}_{\mathrm{s}}=$ number of cells connected in series (36)

- $\mathrm{K}=$ Boltzmann constant $(1.3805 \times 10-23 \mathrm{~J} / \mathrm{K})$

- $\quad \mathrm{A}=$ Ideality factor (1.6)

- $\mathrm{E}_{\mathrm{go}}=$ Band gap energy of the semiconductor (1.1eVfor the polycrystalline $\mathrm{Si}$ at $25^{\circ} \mathrm{C}$ )

\section{MPPT ALGORITHM}

\subsection{Enhanced Adaptive Perturb and Observe Algorithm}

The drawbacks of the conventional P\&O algorithm can be eliminated with the proposed enhanced adaptive technique. This work ensures the steady state oscillation and decrease in tracking loss deviation. The tracking of global peak power under partial shading is also carried out. Based on the literature survey [11-12], the initial perturbation is set. After that, the algorithm reads the voltage and current values from the PV array. This power is compared with the normalized values during the initial scanning state. When it reaches the maximum power point, it starts oscillating and then five consecutive perturbations are recorded and the oscillations are detected by the enhanced adaptive algorithm [13]. After detecting the oscillation, the perturbation is minimized to the threshold level and the value of 'steady' is set to 1 . Now the voltage of the PV is expected to be at MPP since the irradiation level is maintained at a uniform level. After tracking the optimum point, a boundary condition is set on the voltage value at MPP [14-15].

Under partial shading condition, local peaks occur at certain conditions. When the shading level increases gradually with respect to the number of series modules, the local peaks position gets shifted towards right. Therefore, it is necessary to shift the predicted points to the right along with the increasing shading level. The scanning points are set to $\mathrm{V}_{1}, \mathrm{~V}_{2}, \ldots \ldots \mathrm{V}_{\mathrm{Ns}}$. The value of current is determined by choosing the point which is close to the short circuit current and it is used to compute the irradiance level. Then it is shifted to $\mathrm{V}_{2}$ and the value 
of $\mathrm{I}_{2}$ is noted. In the same manner, the EAPO service the change of irradiance level and shifts the peak points [16]. After scanning all the predicted peak points, the scanned power will be compared. By comparing the obtained values, the global peak point is determined. The EAPO algorithm is demonstrated using a flow chart and is shown in Fig. 2.

\section{HIGH GAIN DC-DC BOOST CONVERTER}

Normally, classical boost converters are employed for PV applications, but they suffer from severe voltage and current stress when operated at large duty ratios to achieve high gain. Moreover, it produces high ripple both at the input and output side. This can be overcome with the help of a high gain DC-DC converter. Several high gain converter topologies are discussed by various researchers [17-21] and this paper focuses on a topology which combines the conventional boost and quadratic boost to achieve high gain and efficiency. The circuit diagram for the proposed high gain DC-DC converter is shown in Fig. 3.

The operation of the converter is explained in two modes.

Mode-1: Initially, the switch is in ON state and the diodes $\mathrm{D}_{1}$ and $\mathrm{D}_{4}$ gets turned-on simultaneously. The current through the capacitors are equal to that of the opposite inductors. The difference in the voltage levels i.e. $\left(\mathrm{V}_{\mathrm{cl}}-\right.$ $\left.\mathrm{V}_{\mathrm{c} 3}\right)$ and $\left(\mathrm{V}_{\mathrm{c} 2}-\mathrm{V}_{\mathrm{O}}\right)$ leads to the turning off of the diodes $\mathrm{D}_{2}$ and $\mathrm{D}_{5}$. Then diode $\mathrm{D}_{3}$ is reverse based by the voltage $\left(-\mathrm{V}_{\mathrm{c} 2}\right)$.

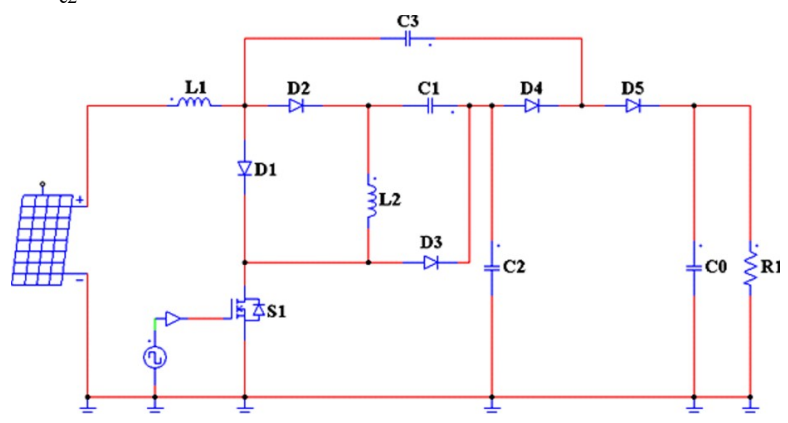

FIG. 3. HIGH GAIN DC-DC CONVERTER
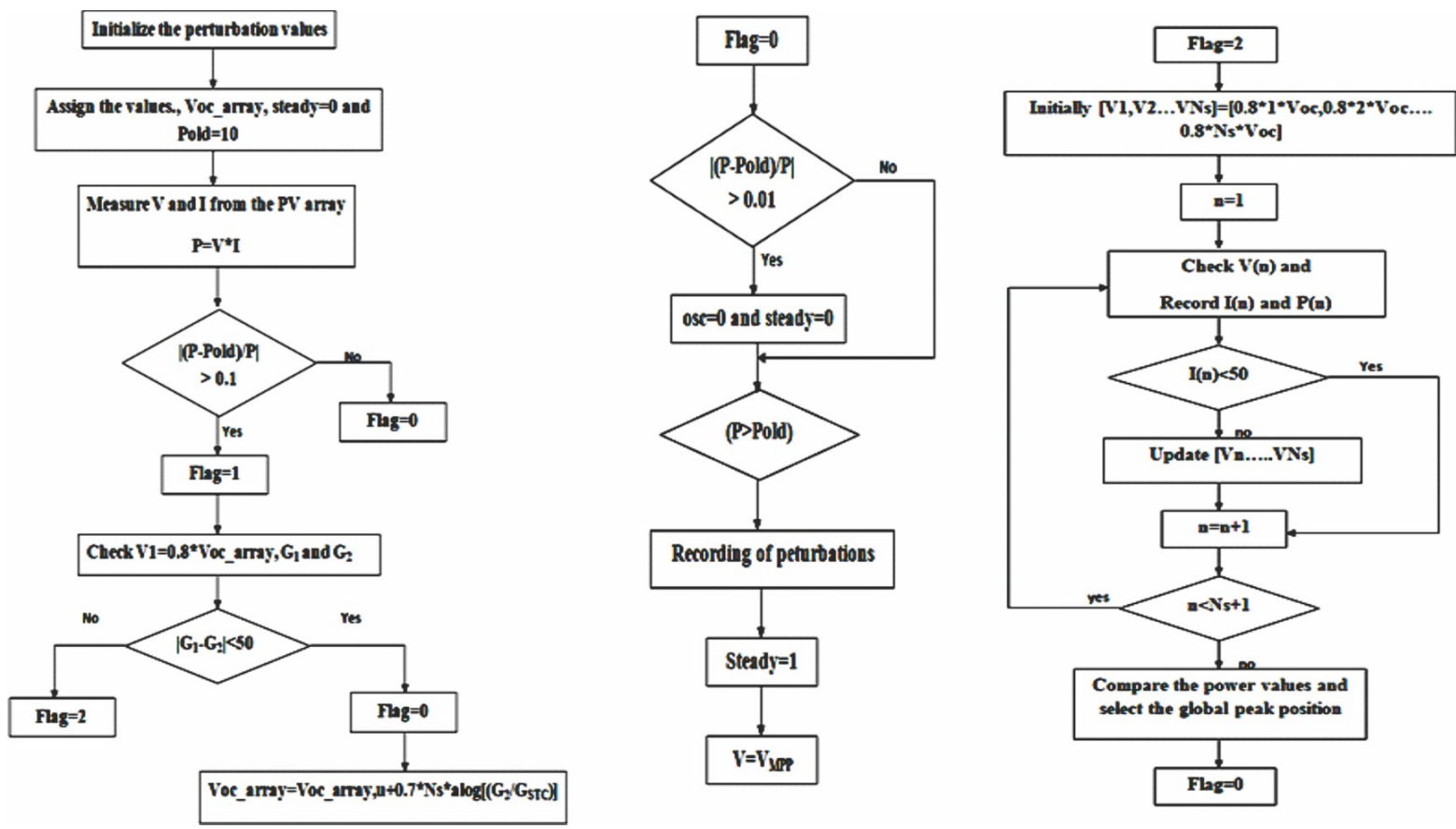

FIG. 2. FLOWCHART FOR ENHANCED ADAPTIVE P\&O ALGORITHM

Mehran University Research Journal of Engineering \& Technology, Volume 38, No. 3, July, 2019 [p-ISSN: 0254-7821, e-ISSN: 2413-7219] 
The value of the voltage in inductor $\mathrm{L}_{1}$ is nothing but the input voltage $\mathrm{V}_{\mathrm{g}}$, and the voltage in inductor $\mathrm{L}_{2}$ is equal to the difference of the capacitor voltages $\mathrm{C}_{1}$ and $\mathrm{C}_{2}$. The value of current in capacitors $\mathrm{C}_{1}$ and $\mathrm{C}_{2}$ is equal to that of the current flowing through inductor $\mathrm{L}_{2}$ and $\mathrm{L}_{1}$ respectively. At this condition the charging of capacitor $\mathrm{C}_{2}$ takes place.

Mode-2: In this mode, the diodes $\mathrm{D}_{2}, \mathrm{D}_{3}$ and $\mathrm{D}_{5}$ get turnedon at the time when the switch is in OFF state. Now the voltage across capacitors becomes equal and the current through the inductors starts decreasing linearly. The voltage across the capacitor $\mathrm{C}_{1}$ makes the diode $\mathrm{D}_{1}$ to become reverse bias and the negative voltage $\left(\mathrm{V}_{\mathrm{c} 2}-\mathrm{V}_{\mathrm{c} 0}\right)$ across the capacitors $\mathrm{C}_{2}$ and $\mathrm{C}_{3}$ makes the diode $\mathrm{D}_{4}$ to be turned off. The decrease in inductor currents $i_{L 1}$ and $i_{L 2}$ is proportional to the voltage $\left(\mathrm{V}_{\mathrm{g}}+\mathrm{V}_{\mathrm{c} 3}-\mathrm{V}_{\mathrm{O}}\right)$ and $\left(-\mathrm{V}_{\mathrm{cl}}\right)$. Capacitor $\mathrm{C}_{2}$ and $\mathrm{C}_{3}$ are being charged by the currents across inductor $\mathrm{L}_{1}$. The converter is designed using the following equations,

The value of inductor, $\mathrm{I}_{1}=\frac{\mathrm{D} \cdot \mathrm{Vin}}{2 \mathrm{fs} \Delta I L 1}$

The value of inductor, $\mathrm{I}_{2}=\frac{\mathrm{D} \cdot \mathrm{Vin}}{2 \mathrm{fs} \Delta I L 2}$

where, $\mathrm{D}$ is the duty ratio, $\mathrm{V}_{\text {in }}$ is the input voltage, $\mathrm{f}_{\mathrm{s}}$ is the switching frequency, $\mathrm{I}_{\mathrm{L} 1}$ is the current through inductor $\mathrm{L}_{1}, \mathrm{I}_{\mathrm{L} 2}$ is the current through inductor $\mathrm{L}_{2}$

The current across the inductor $\mathrm{L}_{1}$ is,

$\mathrm{I}_{\mathrm{L} 1}=\frac{\mathrm{I}_{\mathrm{o}}}{(1-\mathrm{D})^{2}}$ where, $I_{o}$ is the output current

The current across the inductor $\mathrm{L}_{2}$ is,

$$
\mathrm{I}_{\mathrm{L} 2}=\frac{\mathrm{I}_{\mathrm{o}}}{1-\mathrm{D}}
$$

The voltage across the inductor is,

$\mathrm{V}_{\mathrm{L} 1}=\mathrm{V}_{\text {in }}$

where, $\mathrm{V}_{\text {in }}$ is the input voltage

The voltage across the inductor is

$\mathrm{V}_{\mathrm{L} 2}=\mathrm{V}_{\mathrm{cl}}-\mathrm{V}_{\mathrm{c} 2}$

Where, $\mathrm{V}_{\mathrm{c} 1}$ and $\mathrm{V}_{\mathrm{c} 2}$ are the voltages across capacitors $\mathrm{C}_{1}$ and $\mathrm{C}_{2}$ respectively.

The value of the capacitor $\mathrm{C}_{1}$ is,

$$
\mathrm{C}_{1}=\frac{\mathrm{I}_{\mathrm{oD}}}{(1-\mathrm{D}) \Delta \mathrm{Vc} 1 \mathrm{fs}}
$$

The value of the capacitor $\mathrm{C}_{2}$ and $\mathrm{C}_{3}$ is,

$$
=\frac{\mathrm{I}_{\mathrm{oD}}}{\Delta \mathrm{Vc} 2 \mathrm{fs}}
$$

Where,

$$
\begin{aligned}
& \mathrm{V}_{\mathrm{Cl}}=\mathrm{V}+ \\
& \mathrm{C}_{2}=\frac{\mathrm{VS}}{1-\mathrm{D}}
\end{aligned}
$$

The voltage across the capacitors are,

$\mathrm{V}_{\mathrm{c} 2}=\mathrm{V}_{\mathrm{c} 3}$ 
$\mathrm{V}_{\mathrm{cl}}=2 \mathrm{~V}_{\mathrm{c} 2}-\mathrm{V}_{\mathrm{o}}$

$\mathrm{V}_{\mathrm{c} 2}=[1 /(2-\mathrm{D})] \mathrm{V}_{\mathrm{o}}$

$\mathrm{V}_{\text {in }}=\mathrm{D}^{\prime}\left(\mathrm{V}_{\mathrm{o}}-\mathrm{V}_{\mathrm{c} 3}\right)$

Where, $D^{\prime}=(1-D), D_{\text {is }}$ the duty ratio, $V_{\text {in }}$ is the input voltage, $\mathrm{V}_{\mathrm{o}}$ is the output voltage.

The voltage gain for the converter is given by,

Voltage gain, $\mathrm{M}=\left(\mathrm{V}_{\mathrm{o}} / \mathrm{V}_{\text {in }}\right)=\frac{2-\mathrm{D}}{(1-\mathrm{D})^{2}}$

Using the above equations, the simulation parameters are designed for the high gain converter and it is shown in Table 1.

\section{SIMULATION RESULTS}

The PV modelling is done using MATLAB/SIMULINK and the results are shown in Fig. 4. The model has been designed for $250 \mathrm{~W}$, the PV and IV characteristics for the panel is shown in Figs. 5-6 respectively.
From Fig. 5, it is clear that the maximum power occurs at a value which is nearer to $250 \mathrm{~W}$ with respect to that of the open circuit voltage.

Fig.6., shows the waveform for short circuit current with respect to that of the open circuit voltage. The curve indicates that the rated value of current is obtained.

The dynamic power waveforms for the MPPT algorithms are shown in Fig. 7.

TABLE 1. SPECIFICATION OF HIGH GAIN BOOST CONVERTER

\begin{tabular}{|c|c|}
\hline Parameters & Range \\
\hline Input Voltage, Vin & $37.8 \mathrm{~V}$ \\
\hline Inductance, $\mathrm{L} 1$ & $5 \mathrm{mH}$ \\
\hline Inductance, $\mathrm{L} 2$ & $25 \mu \mathrm{H}$ \\
\hline Capacitance, $\mathrm{C} 1$ & $50 \mu \mathrm{F}$ \\
\hline Capacitance, $\mathrm{C} 2$ and $\mathrm{C} 3$ & $100 \mu \mathrm{F}$ \\
\hline Output Capacitance, C0 & $1000 \mu \mathrm{F}$ \\
\hline Resistance, R1 & $250 ?$ \\
\hline Duty ratio & 0.4 \\
\hline Switching Frequency, fs & $90 \mathrm{kHz}$ \\
\hline
\end{tabular}

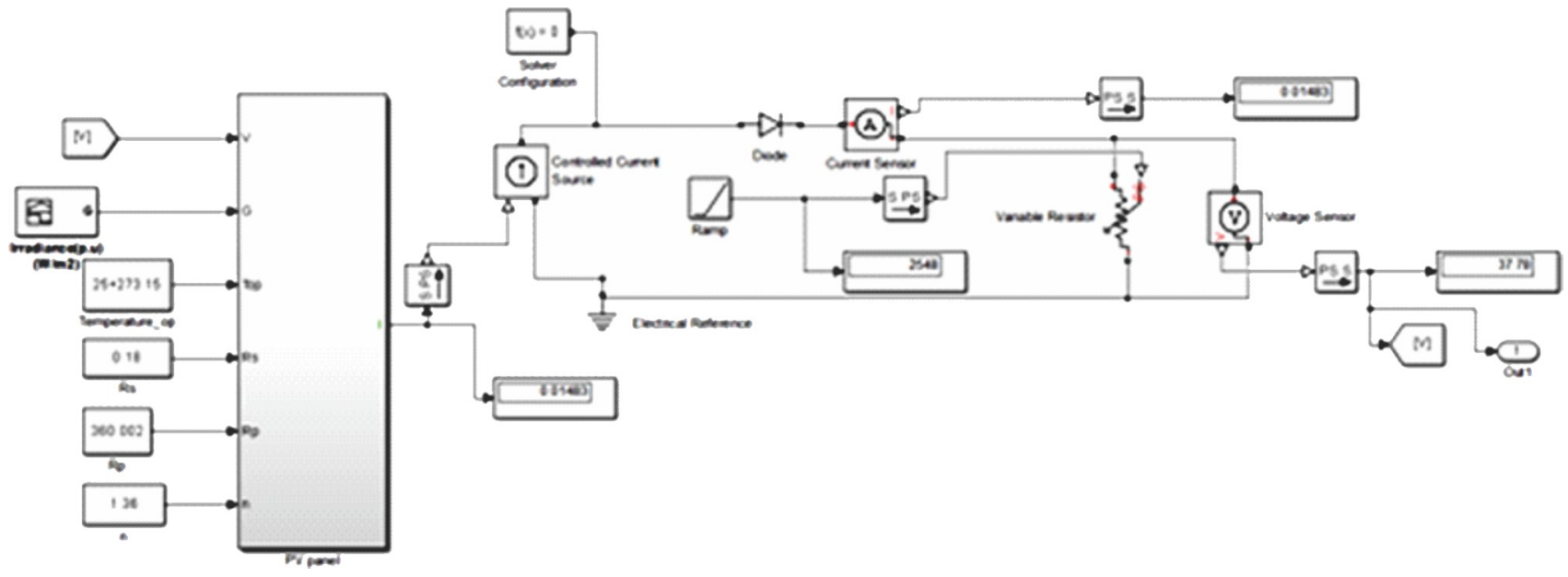

FIG. 4. SIMULINK MODEL FOR PV PANEL 
Fig. 7, shows the dynamic power waveform for the proposed MPPT algorithm along with the basic perturb and observe and adaptive perturb and observe algorithm. The proposed enhanced adaptive $\mathrm{P} \& \mathrm{O}$ algorithm is compared with the other conventional $\mathrm{P} \& \mathrm{O}$ algorithms based on tracking efficiency and the results are tabulated in Table 2.

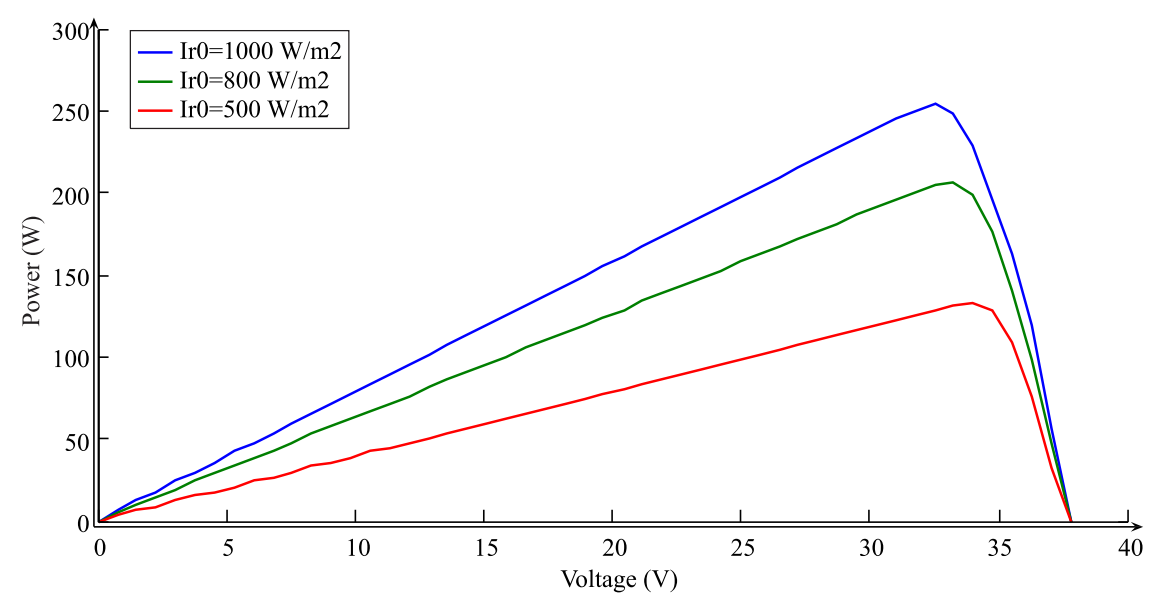

FIG. 5. P-V CHARACTERISTICS

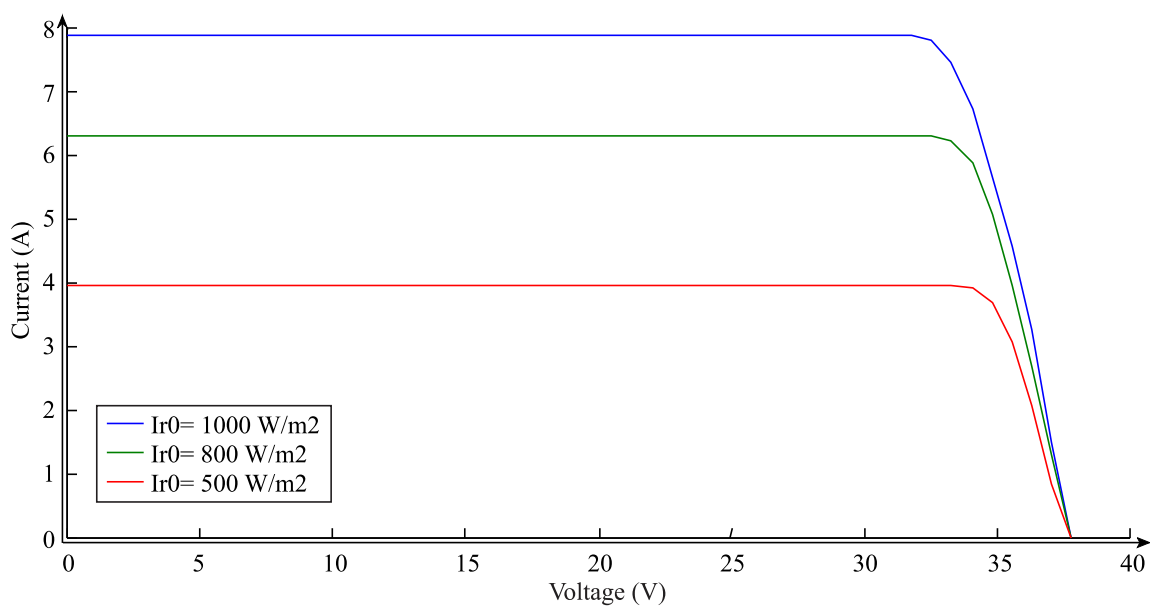

FIG. 6. I-V CHARACTERISTICS

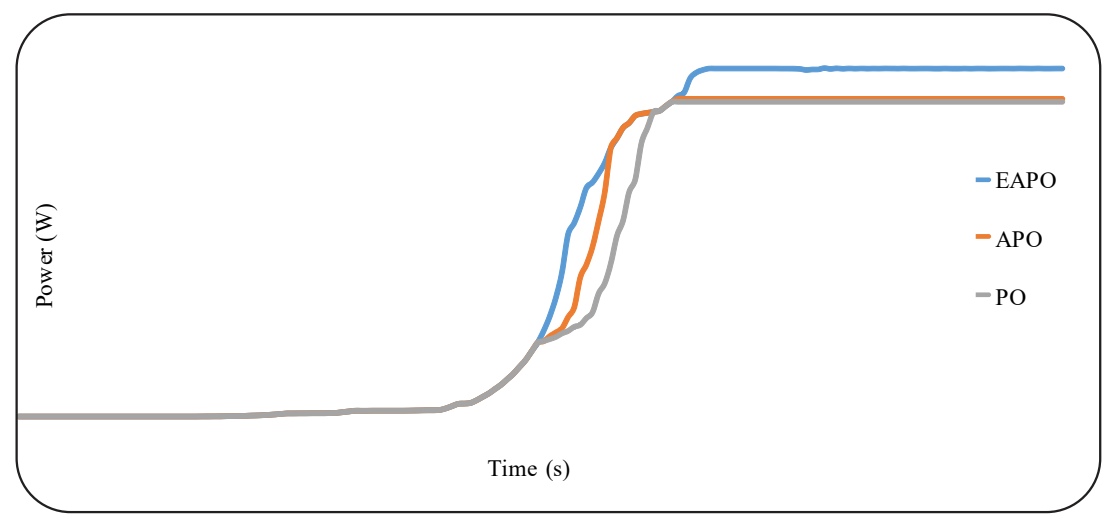

FIG. 7. POWER WAVEFORM FOR MPPT ALGORITHMS

Mehran University Research Journal of Engineering \& Technology, Volume 38, No. 3, July, 2019 [p-ISSN: 0254-7821, e-ISSN: 2413-7219] 
From Table 2, it is found that the proposed MPPT algorithm is very efficient when compared to the other MPPT techniques. The tracking efficiency is $95.62 \%$

Fig. 8 shows the generated gate pulses after the implementation of enhanced adaptive MPPT algorithm.

\section{TABLE 2. TRACKING EFFICIENCY FOR MPPT ALGORITHMS}

\begin{tabular}{|c|c|}
\hline Algorithms & $\begin{array}{c}\text { Tracking Efficiency } \\
(\%)\end{array}$ \\
\hline Peturb \& Observe & 88.65 \\
\hline Adaptive Peturb \& Observe & 90.63 \\
\hline Enhanced Adaptive Peturb \& Observe & 95.62 \\
\hline
\end{tabular}

The simulation of high gain DC-DC converter is carried out using MATLAB/SIMULINK for an input voltage of 37.8V. The Simulink model is shown in Fig. 9.

The waveforms for voltage, current and power are shown in Figs. 10-12 respectively.

Fig. 10 shows the waveform for output voltage of the high gain converter. The output voltage is in the range of $146.3 \mathrm{~V}$ and the ripple is also low. The output voltage ripple waveform is shown in Fig. 11.

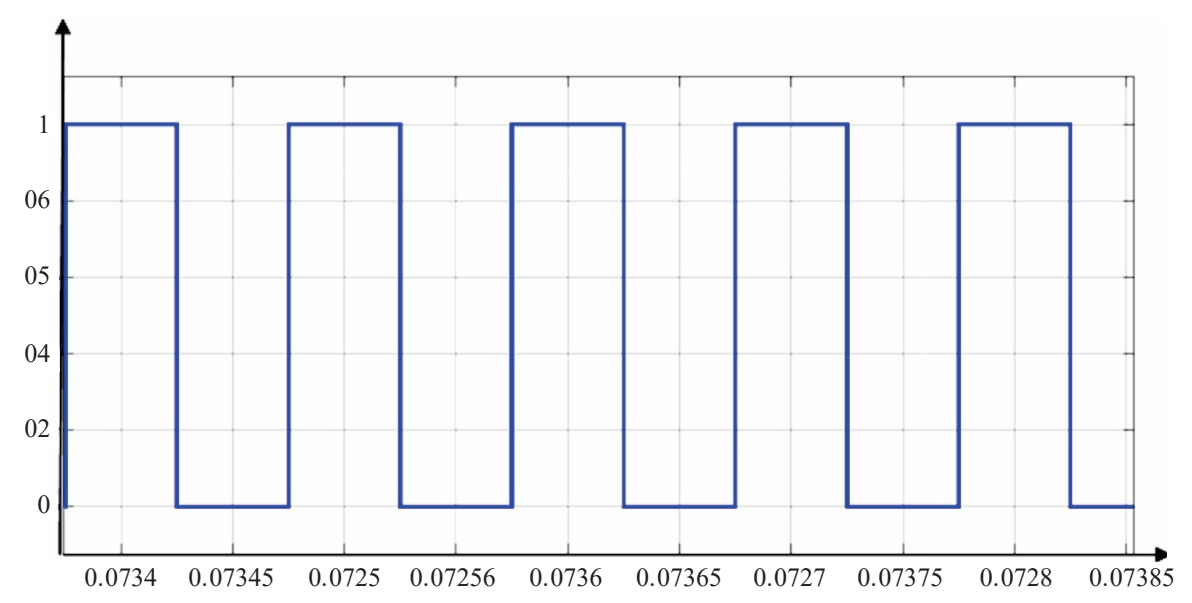

FIG. 8. PULSE GENERATED AFTER MPPT ALGORITHM

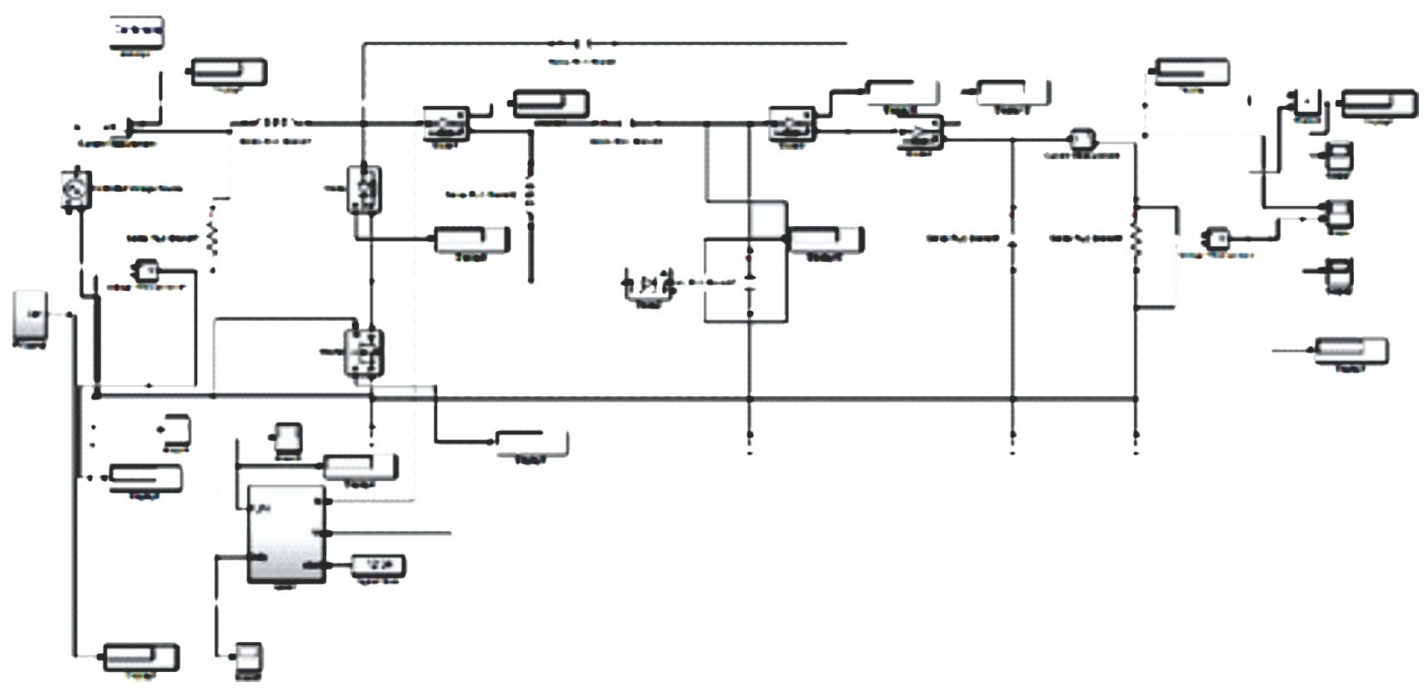

FIG. 9. MATLAB/SIMULINK MODEL FOR HIGH GAIN DC-DC CONVERTER 
From Fig. 11, it is found that the output voltage ripple is in the range of $0.018 \mathrm{~V}$ which is a low ripple value.
Fig. 12 shows the waveform for the output current. The current is maintained at $1.656 \mathrm{~A}$ with less ripple content. The waveform is shown in Fig. 13.

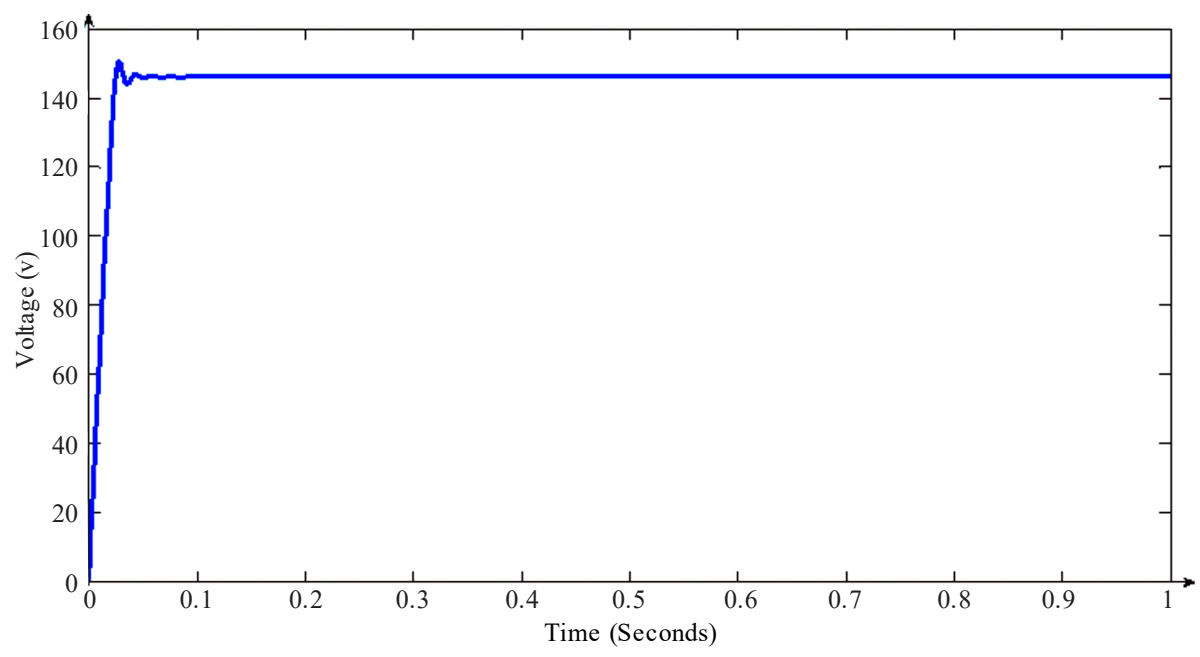

FIG. 10. OUTPUT VOLTAGE WAVEFORM FOR HIGH GAIN DC-DC CONVERTER

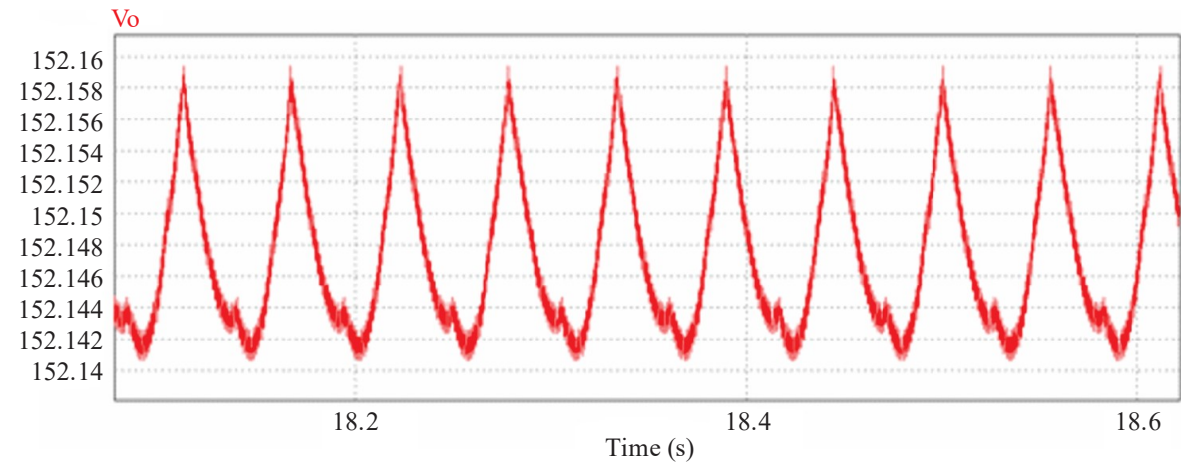

FIG. 11. OUTPUT VOLTAGE RIPPLE

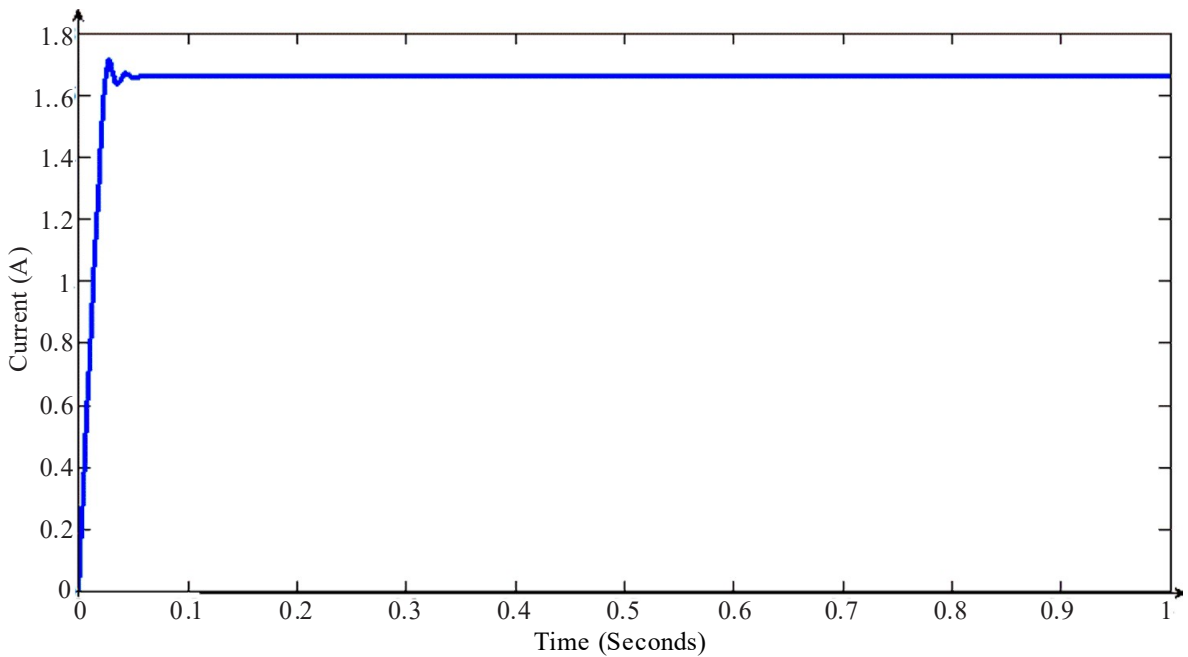

FIG. 12. OUTPUT CURRENT WAVEFORM FOR HIGH GAIN DC-DC CONVERTER

Mehran University Research Journal of Engineering \& Technology, Volume 38, No. 3, July, 2019 [p-ISSN: 0254-7821, e-ISSN: 2413-7219] 
From Fig. 13, it is clearly indicated that the input current ripple is in the range of $0.03 \mathrm{~A}$ which is a low ripple value.

From Fig. 14, it is found that the maximum power has been achieved. It is in the range of $242.2 \mathrm{~W}$ and the required power rating is $250 \mathrm{~W}$.
The voltage stress across the main devices for the proposed topology is shown in Fig. 15.

Fig.15., shows the waveform for voltage stress across the MOSFET switch and the conducting diodes for the proposed topology. From Fig. 15, it is clear that the voltage stress is at nominal level.

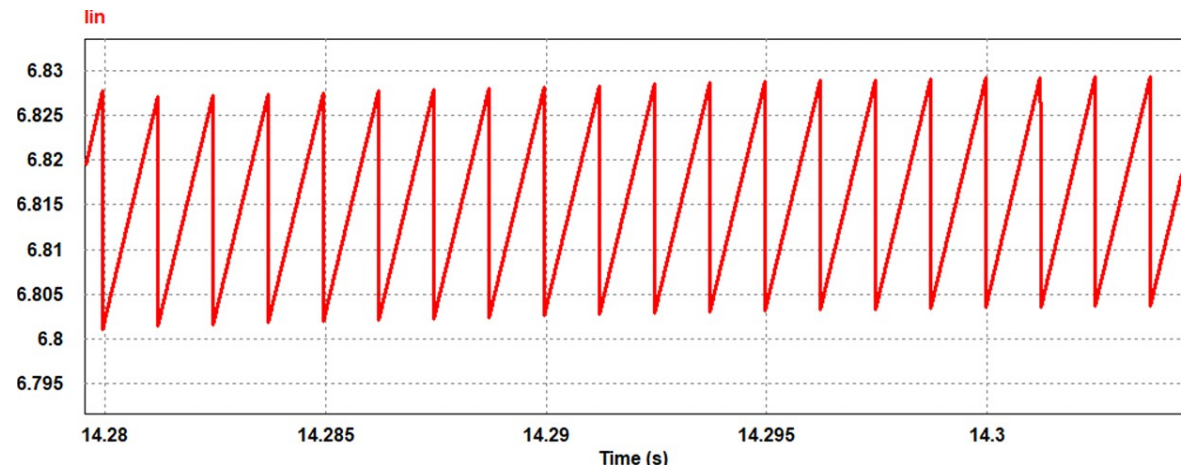

FIG. 13. INPUT CURRENT RIPPLE

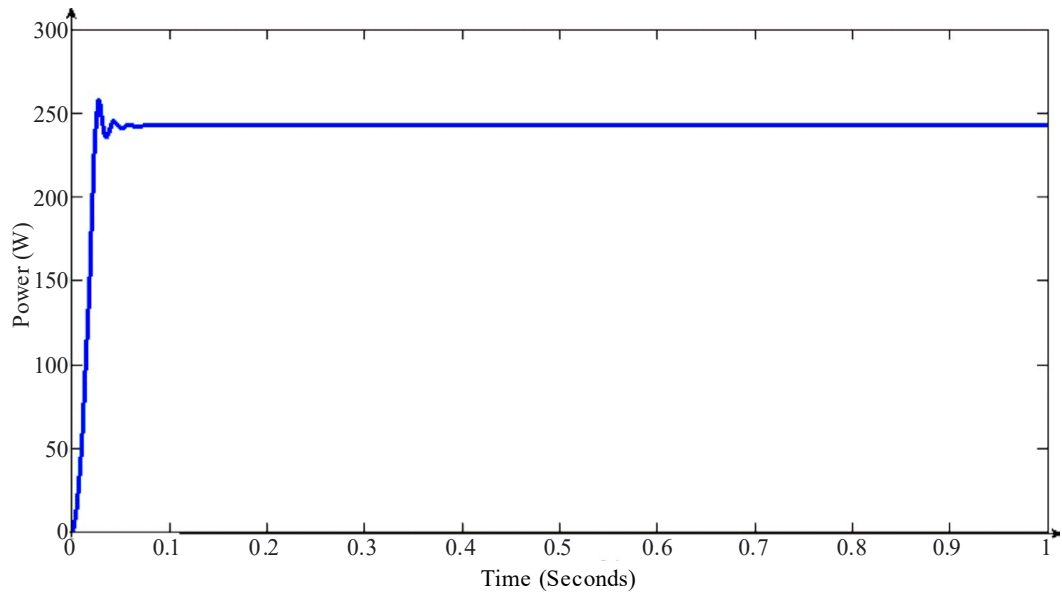

FIG. 14. OUTPUT POWER WAVEFORM FOR HIGH GAIN DC-DC CONVERTER

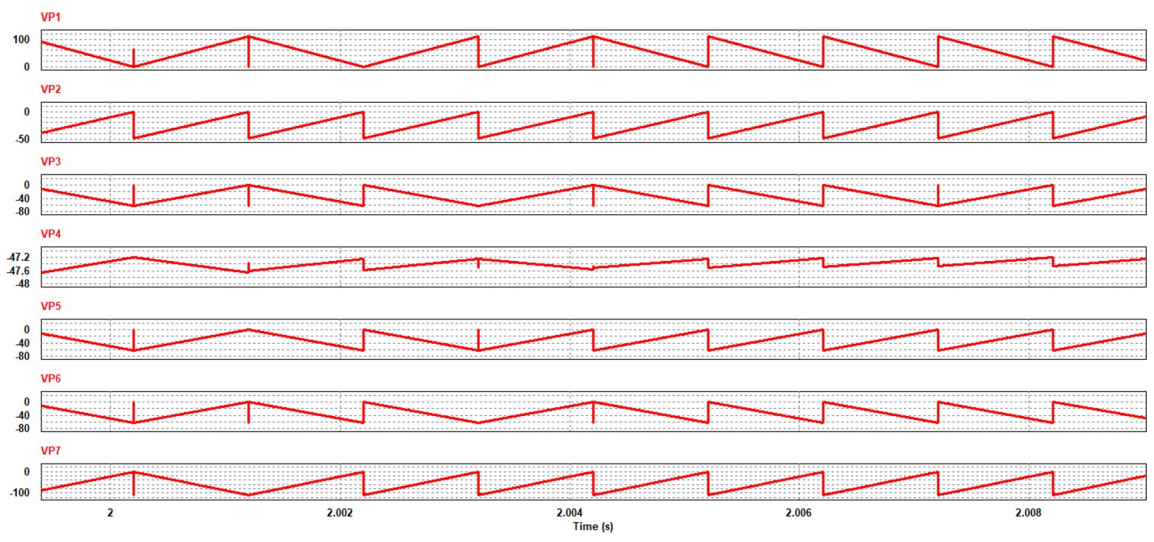

FIG. 15. VOLTAGE STRESS ACROSS THE SWITCHING DEVICES 
A graph drawn between the percentage of efficiency with respect to the load for the high gain converter topology is shown in Fig. 16.

From Fig.16, it is clear that the proposed converter gives an efficiency of $95.6 \%$ at full load.

The high gain converter investigated in this paper is compared with some other topologies of boost converter based on the parameters such as output voltage ripple, input current ripple, duty ratio, voltage gain and voltage and current stress across the main switch. The comparison of parameters is shown in Table 3.

From Table 3, it is clear that the proposed high gain converter is efficient in terms of ripple voltage, ripple current, duty ratio and voltage gain when compared to the other boost converter topologies.

The high gain topologies are also compared based on the number of devices used, control complexity and filter components. The comparison is shown in Table 4.

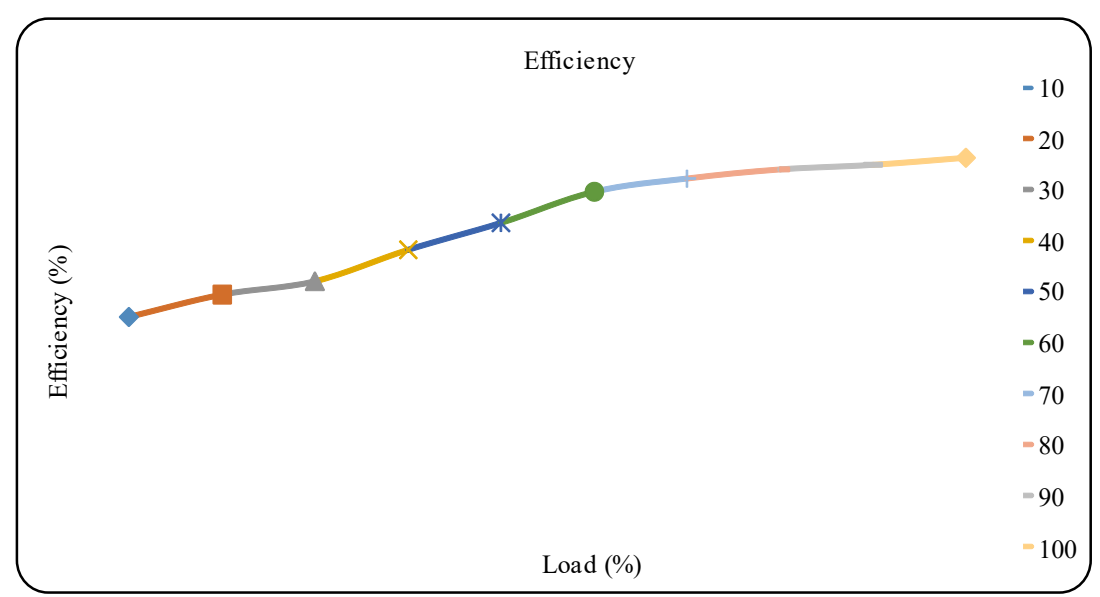

FIG. 16. EFFICIENCY CURVE

TABLE 3. COMPARISON OF PARAMETERS

\begin{tabular}{|c|c|c|c|c|c|}
\hline Parameters & $\begin{array}{c}\text { Cascaded Boost with } \\
\text { Single Switch }\end{array}$ & $\begin{array}{c}\text { New Cascaded Boost } \\
\text { with Reduced Losses }\end{array}$ & $\begin{array}{c}\text { Single Switch Inductor } \\
\text { Capacitor Topology }\end{array}$ & $\begin{array}{c}\text { Quadratic DC-DC with Proposed High Gain DC- } \\
\text { Coupled Inductor } \\
\text { DC Converter }\end{array}$ \\
\hline Output Voltage Ripple (V) & 0.1 & 0.5 & 0.2 & 0.04 \\
\hline Input Current Ripple (A) & 0.3 & 0.78 & 0.1 & 0.018 \\
\hline Duty Ratio & 0.4 & 0.4 & 0.4 & 0.03 \\
\hline Voltage Gain & 1.67 & 2.78 & 2.02 & 0.4 \\
\hline
\end{tabular}

TABLE 4. COMPARISON OF TOPOLOGIES

\begin{tabular}{|c|c|c|c|c|c|}
\hline Descriptions & $\begin{array}{c}\text { Cascaded Boost with } \\
\text { Single Switch }\end{array}$ & $\begin{array}{c}\text { New Cascaded Boost } \\
\text { with Reduced Losses }\end{array}$ & $\begin{array}{c}\text { Single Switch Inductor } \\
\text { Capacitor Topology }\end{array}$ & $\begin{array}{c}\text { Quadratic DC-DC } \\
\text { with Coupled Inductor }\end{array}$ & $\begin{array}{c}\text { Proposed High Gain } \\
\text { DC-DC Converter }\end{array}$ \\
\hline No. of Main Switches & 1 & 2 & 1 & 4 \\
\hline No. of Diodes & 3 & 2 & 3 & 0 \\
\hline Noof Inductors & 4 & 4 & 5 & 5 \\
\hline Control Complexity & Difficult & Complex control circuit & Complex & $\begin{array}{c}\text { Need Individual circuit } \\
\text { by simply obtaining a } \\
\text { critical point }\end{array}$ \\
\hline
\end{tabular}

Mehran University Research Journal of Engineering \& Technology, Volume 38, No. 3, July, 2019 [p-ISSN: 0254-7821, e-ISSN: 2413-7219] 
From Table 4, it is clear that the proposed high gain converter is best in terms of reduced number of main switching devices and also in controlling aspects.

The voltage and current stress values for the converter topologies are tabulated in Table 5.

The waveforms for the ripple values and voltage gain with respect to the duty ratios are shown in Figs.17-19 respectively.

Fig. 17, shows the variation in input current ripple by varying the duty ratio for some of the high gain converter topologies discussed in the literature. It is clear that the high gain DC-DC converter investigated in this paper has very low current ripple compared to the other topologies. It is in the range of $0.03 \mathrm{~A}$.
Fig. 18, shows the variation in output voltage ripple by varying the duty ratio. It is clear that the high gain DCDC converter investigated in this paper has very low voltage ripple compared to the other topologies. It is in the range of $0.018 \mathrm{~V}$

The variation of voltage gain with respect to the duty ratio is shown in Fig. 19, and it is found that high conversion gain can be achieved even at low duty ratio. For the required power rating, high voltage conversion has been achieved at a duty ratio of 0.4

The full load efficiency for all the discussed topologies is shown in Table 6.

From table 6 , it is clear that the proposed topology is highly efficient compared to the other topologies.

TABLE 5. VOLTAGE AND CURRENT STRESS CALCULATION

\begin{tabular}{|c|c|c|}
\hline Topologies & Voltage Stress (V) & Current Stress (A) \\
\hline Cascaded boost with single switch & 45.29 & 4.3 \\
\hline New cascaded boost with reduced losses & 75.75 & 3.2 \\
\hline Single switch inductor capacitor topology & 21.7 & 5.4 \\
\hline Quadratic DC-DC with coupled inductor & 69.12 & 3.1 \\
\hline
\end{tabular}

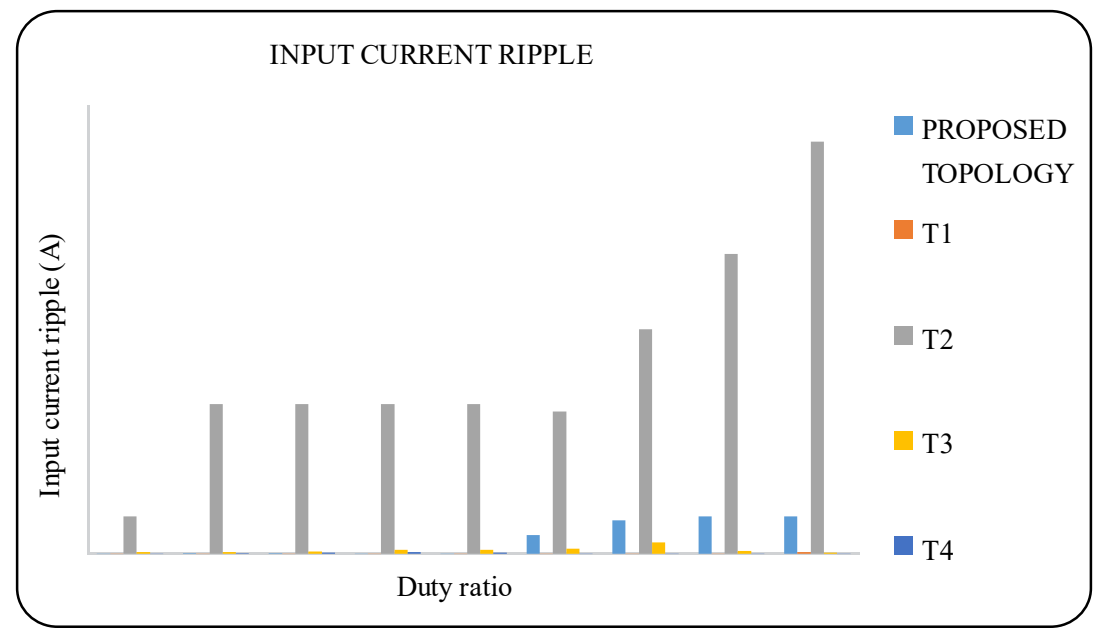

FIG. 17. WAVEFORM FOR INPUT CURRENT RIPPLE 
TABLE 6. EFFICIENCY FOR CONVERTER TOPOLOGIES

\begin{tabular}{|c|c|}
\hline Topologies & Efficiency (\%) \\
\hline Cascaded boost with single switch & 91.2 \\
\hline New cascaded boost with reduced losses & 92.5 \\
\hline Single switch inductor capacitor topology & 77 \\
\hline Quadratic DC-DC with coupled inductor & 88 \\
\hline High gain DC-DC converter & 95.6 \\
\hline
\end{tabular}

\section{HARDWARE IMPLEMENTATION}

To verify the theoretical results and to measure the performance of the system, the proposed converter topology is simulated and validated with an experimental setup for the following speciûcations: $\mathrm{V}_{\text {in }}=18.3 \mathrm{~V}, \mathrm{~V}_{\mathrm{o}}=84$ $\mathrm{V}$ and $\mathrm{f}_{\mathrm{s}}=90 \mathrm{kHz}$. The inductors values are $5 \mathrm{mH}, 25 \mu \mathrm{H}$ for $\mathrm{L}_{1}$ and $\mathrm{L}_{2}$ respectively. The value of the capacitor is 50 $\mu \mathrm{F}$ for $\mathrm{C}_{1}$ and $100 \mu \mathrm{F}$ for $\mathrm{C}_{2}$ and $\mathrm{C}_{3}$. The output capacitor

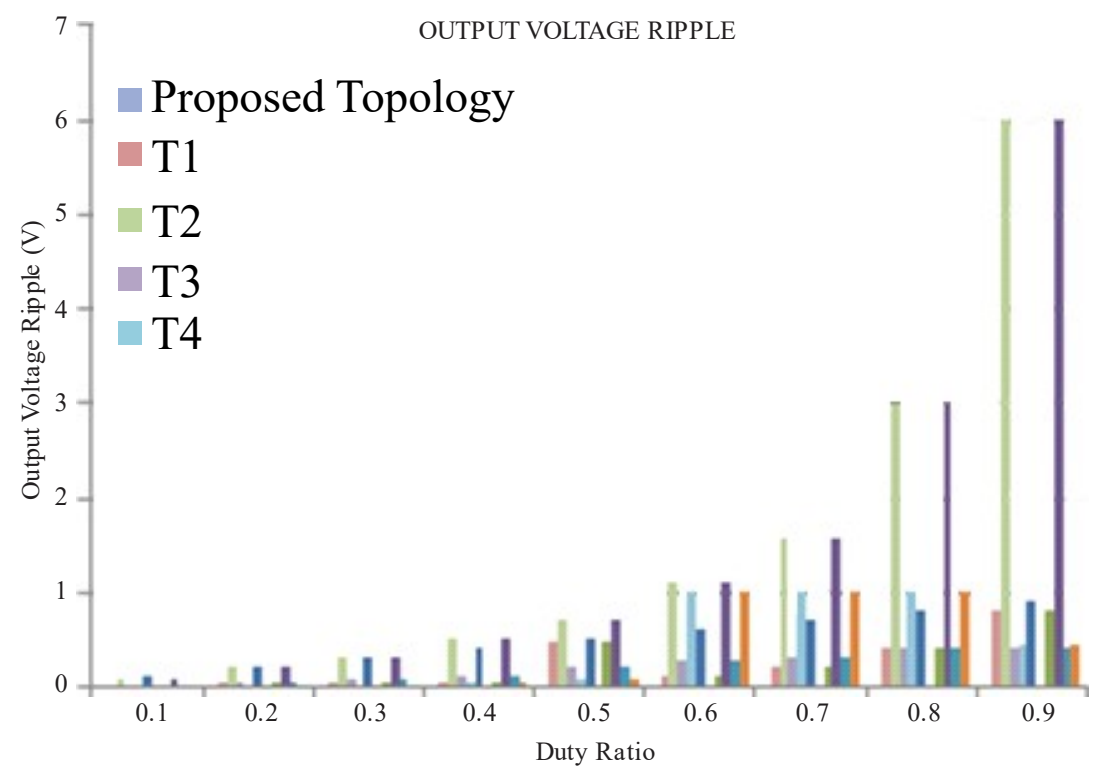

FIG. 18. WAVEFORM FOR OUTPUT VOLTAGE RIPPLE

Voltage Gain

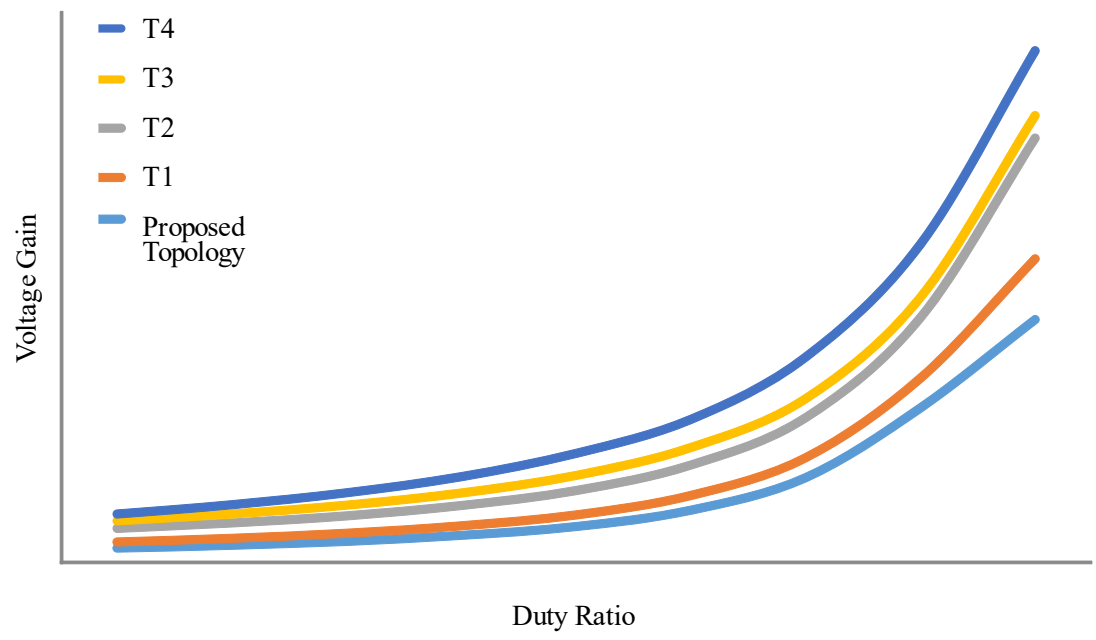

FIG. 19. WAVEFORM FOR VOLTAGE GAIN AT DIFFERENT DUTY RATIOS 
$\left(\mathrm{C}_{\mathrm{o}}\right)$ is set to $1000 \mu \mathrm{F}$. The hardware setup of the high gain converter is shown in Fig. 20.

Power MOSFETs are chosen as the semiconductor switch for the proposed converter and gating pulses are generated using the hardware implementation of the converter is shown in Fig. 20. The input voltage of $18.3 \mathrm{~V}$ is given and the voltage is boosted up to 4.45 times which is equal to the simulated results. The obtained output voltage is $84 \mathrm{~V}$.

Fig. 21, shows the gating pulse for the converter circuit. The pulse pattern is programmed using arduino UNO 3 board for a duty ratio of 0.4

Fig. 22, shows the experimental results for the high gain converter. It is clear that output voltage is in the range of $84 \mathrm{~V}$.

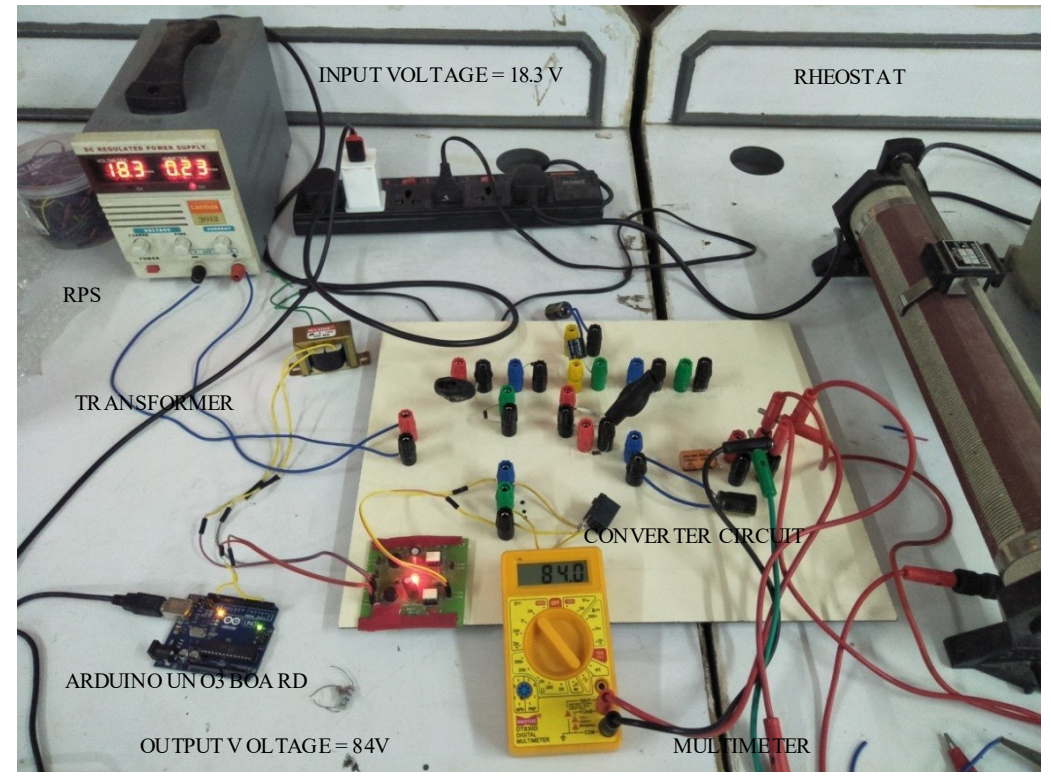

FIG. 20. EXPERIMENTAL SETUP

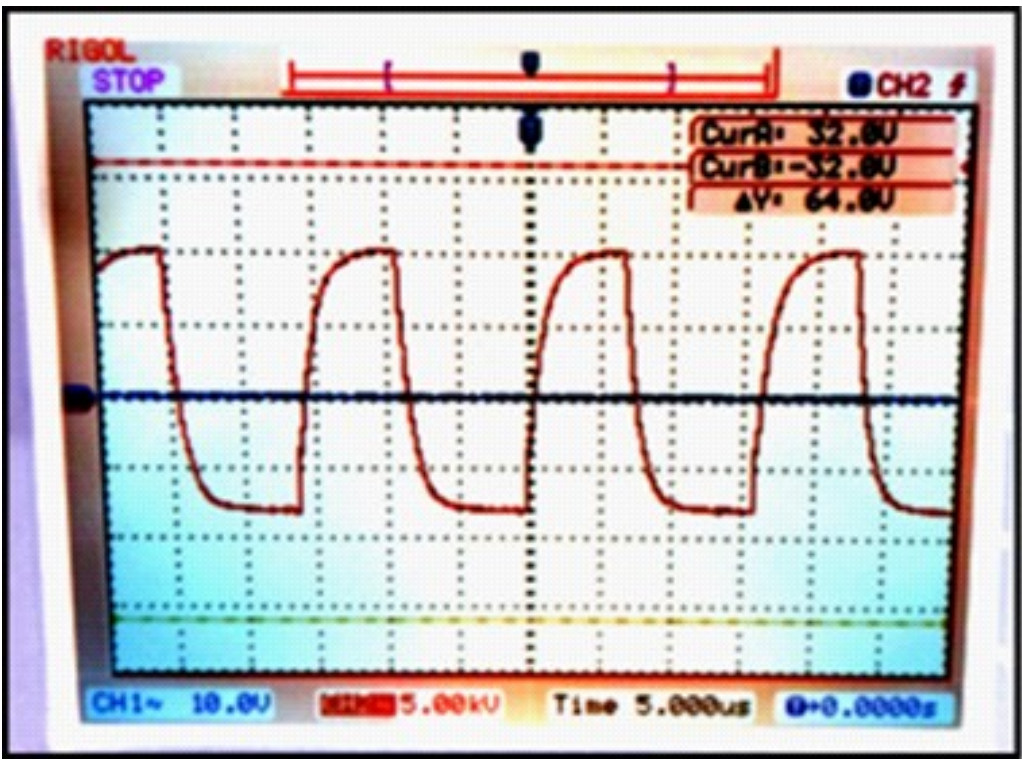

FIG. 21. GATE PULSE FOR CONVERTER

Mehran University Research Journal of Engineering \& Technology, Volume 38, No. 3, July, 2019 [p-ISSN: 0254-7821, e-ISSN: 2413-7219] 


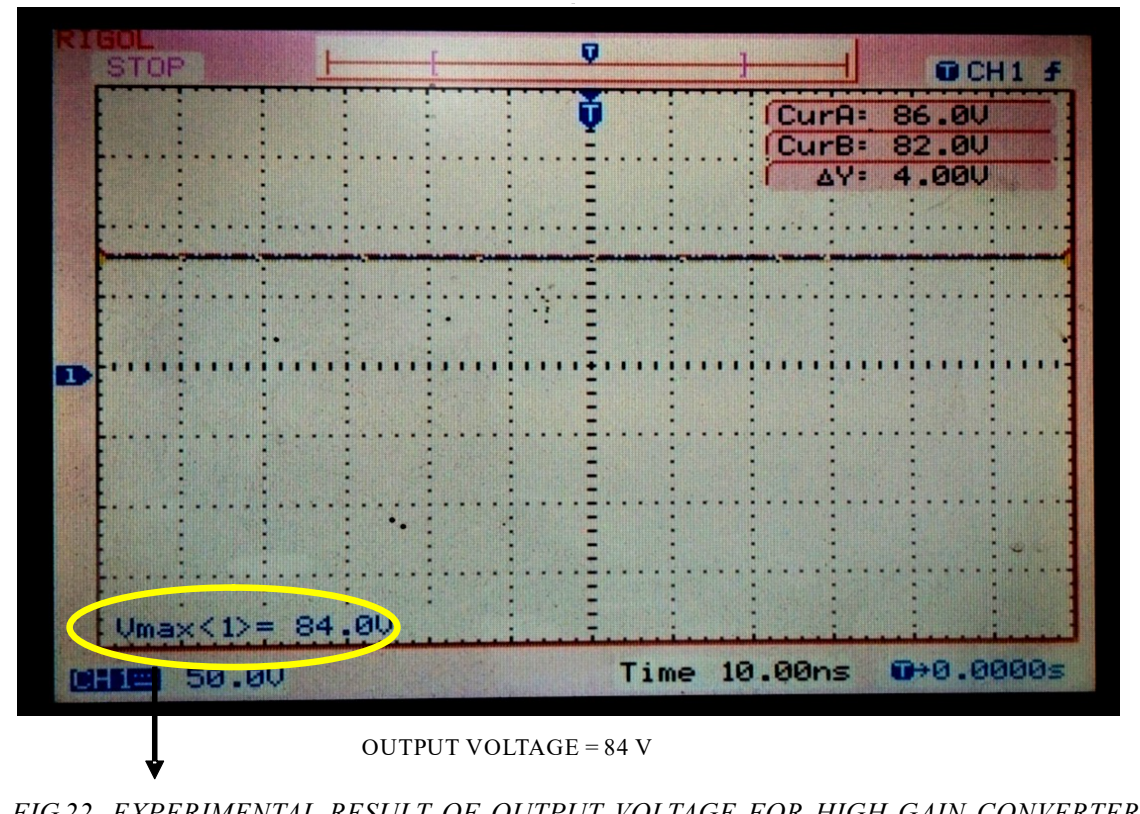

\section{CONCLUSION}

An enhanced adaptive $\mathrm{P} \& \mathrm{O}$ technique is implemented to obtain the maximum power from the solar panel and the PV acts as an input source for the converter configuration. The proposed MPPT algorithm is compared with the basic $\mathrm{P} \& \mathrm{O}$ algorithm and also with an adaptive technique and it is proved to have a very good tracking efficiency of $95.62 \%$. The high gain converter is implemented with the proposed enhanced MPPT technique and results in high voltage gain with less voltage ripple compared to the other conventional topologies discussed. The simulation results are validated using an experimental setup. Hence, the proposed converter topology with high voltage gain ratio is suitable for PV applications.

\section{ACKNOWLEDGEMENT}

The authors wish to acknowledge the support from the management of Department of Electrical and Electronics Engineering, SSN College of Engineering, Chennai, India.

\section{REFERENCES}

[1] Mendalek, N., and Al-Haddad, K., "Photovoltaic System Modeling and Simulation", IEEE Transactions, pp. 1522-1527, 2017.

[2] Christopher. I.W., and Ramesh, R., "Comparative Study of P\&O and InC MPPT Algorithms", American Journal of Engineering Research,Volume2, No. 12, pp. 402-408, 2013.

[3] Cristaldi, L., Faifer, M., Laurano, C., Ottoboni, R., and Toscani, S., "Experimental Comparison of MPPT Algorithms", IEEE Transactions, 23-26 May 2016.

[4] Kollimalla, S.K., and Mishra, M.K., "Variable Perturbation Size Adaptive P\&O MPPT Algorithm for Sudden Changes in Irradiance", IEEE Transactions onSustainable Energy, Volume 5,No. 3, pp. 718-728, July, 2014.

[5] Zhang, F., Thanapalan, K., Procter, A., Carr, S., and Maddy, J., "Adaptive Hybrid Maximum Power Point Tracking Method for a Photovoltaic System”, IEEE Transactions on Energy Conversation, Volume 28, No. 2, pp. 353-360, June, 2013.

Mehran University Research Journal of Engineering \& Technology, Volume 38, No. 3, July, 2019 [p-ISSN: 0254-7821, e-ISSN: 2413-7219] 
[6] Baharudin, N.H., Nizar, T.M., Mansur, T., Hamid, F.A., Ali, R., and Misrun, M.I., "Topologies of DC-DC Converter in Solar PV Applications", Indonesian Journal of Electrical Engineering and Computer Science, Volume 8, No. 2, pp. 368-374, November, 2017.

Zhang, F., Du, I., Peng, F.Z., and Qian, Z., “A New Design Method for High-Power High-Efficiency Switched-Capacitor DC-DC Converters", IEEE Transactions on Power Electronic, Volume 23, No. 2, pp. 832-840, March, 2008 .

Yang, L.S., Liang, T.J., Lee, H.C., and Chen, J.F., "Novel High Step-up DC-DC Converter with Coupled-Inductor and Voltage-Doubler Circuits", IEEE Transactions on Industrial Electronics, Volume 58, No. 9, pp. 4196-4206, September, 2011.

Barreto, L.H., Coelho, F.A., Farias, V.J., de Oliviera, J.C., de Freitas, L.C., and Vieira, I.B., "A Quasi-Resonant Quadratic Boost Converter Using a Single Resonant Network", IEEE Transactions Industrial Electronics, Volume 52, No. 2, pp. 552-557,April, 2005.

[10] Selvan, S., Nair, P., and Umayal, "A Review on Photo Voltaic MPPT Algorithms", International Journal of Electrical and Computer Engineering, Volume 6, No. 2,pp. 567-582, April, 2016.

[11] Ahmed, J., and Salam, Z., "An Enhanced Adaptive P\&O MPPT for Fast and Efûcient Tracking Under Varying Environmental Conditions", IEEE Transactions on Sustainable Energy, Volume 9, No. 3, pp.1487-1496, July, 2018.

[12] Ahmed, J., and Salam, Z., "A Modiûed P\&O Maximum Power Point Tracking Method with Reduced SteadyState Oscillation and Improved Tracking Efûciency", IEEE Transactions onSustainable Energy, Volume 7, No. 4, pp. 1506-1515, October, 2016.

[13] Villalva, M.G., and Gazoli, J.R., "Comprehensive Approach to Modelling and Simulation of Photovoltaic Arrays", IEEE Transactions on Power Electronics, Volume 24, No. 5, pp. 1198-1208, May, 2009.
[14] Patel, H., and Agarwal, V., "Maximum Power Point Tracking Scheme for PV Systems Operating Under Partially Shaded Conditions", IEEE Transactions Industrial Electronics, Volume 55, No. 4, pp. 1689-1698, April, 2008.

[15] Kouchaki, A., Iman-Eini, H., and Asaei, B., "A New Maximum Power Point Tracking Strategy for PV Arrays Under Uniform and Non-Uniform Insolation Conditions", Solar Energy, Volume 91, pp. 221-232, May, 2013.

[16] Ahmed, J., and Salam, Z., "An Improved Method to Predict the Position of Maximum Power Point during Partial Shading for PV Arrays", IEEE Transactions Industrial Information, Volume 11, No. 6 , pp. 1378-1387, December, 2015.

[17] Mitra, L., and Rout, U.K., "Single Switched Inductor Capacitor coupled Transformerless High Gain Converter for PV Application", IEEE Transactions, pp. 1213-1219, 2016.

[18] Ahmad, A., Singh, R.K., and Mahanty, R., "Bidirectional Quadratic Converter for Wide Voltage Conversion Ratio”, IEEE Transactions, 2016.

[19] Morales-Saldaña, J.A., Galarza-Quirino, R., LeyvaRamos, J., Carbajal-Gutierrez, E.E., and Ortiz-Lopez, M.G., "Modeling and Control of a Cascaded Boost Converter with a Single Switch", IEEE Transactions, 2006.

[20] Nejad, M.L., Poorali, B., Adib, E., and Brijandi, A.K.M., "New Cascade Boost Converter with Reduced Losses", IET Power Electronics, Volume 9, No. 6, pp. 1213-1219, 2016

[21] Mohamed, H.E., and Fardoun, A.A., "High Gain DC-DC Converter for PV Applications", IEEE 59th International Transactions on Midwest Symposium on Circuits and Systems, pp. 591596, October, 2016. 